\title{
Flow regime change in an endorheic basin in southern Ethiopia
}

\author{
F. F. Worku ${ }^{1,4,5}$, M. Werner ${ }^{1,2}$, N. Wright ${ }^{1,3,5}$, P. van der Zaag ${ }^{1,5}$, and S. S. Demissie ${ }^{6}$ \\ ${ }^{1}$ UNESCO-IHE Institute for Water Education, P.O. Box 3015, 2601 DA Delft, the Netherlands \\ ${ }^{2}$ Deltares, P.O. Box 177, 2600 MH Delft, the Netherlands \\ ${ }^{3}$ University of Leeds, School of Civil Engineering, Leeds, UK \\ ${ }^{4}$ Arba Minch University, Institute of Technology, P.O. Box 21, Arba Minch, Ethiopia \\ ${ }^{5}$ Department of Water Resources, Delft University of Technology, P.O. Box 5048, 2600 GA Delft, the Netherlands \\ ${ }^{6}$ Ethiopian Institute of Water Resources, Addis Ababa University, P.O. Box 150461, Addis Ababa, Ethiopia
}

Correspondence to: F. F. Worku (f.worku@unesco-ihe.org)

Received: 29 December 2013 - Published in Hydrol. Earth Syst. Sci. Discuss.: 29 January 2014

Revised: - - Accepted: 20 August 2014 - Published: 30 September 2014

\begin{abstract}
Endorheic basins, often found in semi-arid and arid climates, are particularly sensitive to variation in fluxes such as precipitation, evaporation and runoff, resulting in variability of river flows as well as of water levels in endpoint lakes that are often present. In this paper we apply the indicators of hydrological alteration (IHA) to characterise change to the natural flow regime of the Omo-Ghibe Basin in southern Ethiopia. Little water resource infrastructure has been developed in the basin to date, and it is considered pristine. The basin is endorheic and is the main source of flow to Lake Turkana in the East African Rift Valley. The water level in Lake Turkana shows significant fluctuation, but increase of its level can be observed over the past 20 years. The reasons are currently not well understood.

Of the five groups of hydrological characteristics in the IHA (magnitude, timing, duration, frequency and variability), only those related to magnitude were found to show significant trends, with the main trend being the increase of flow during the dry season. This trend was not reflected in climatological drivers such as rainfall, evaporation and temperature (which shows a positive trend), but rather is attributed to the substantial changes in land use and land cover in the basin. The change in the basin hydrology is apparent mainly in the more humid part of the basin. The significant shift from forest and woodland to grassland and cropland results in a decrease of actual evaporation and subsequent increase in (dry season) runoff. The long-term trend of the increasing levels in Lake Turkana are related to these trends in dry season flows, while shorter-term fluctuations of the lake levels are attributed primarily to anomalies in consecutive wet and dry season rainfall.
\end{abstract}

\section{Introduction}

Understanding the hydrology of a river and its historical flow characteristics is essential for water resources planning, developing ecosystem services, and carrying out environmental flow assessments. Key hydrological variables can be used to characterise the natural flow regime (NFR) of a river. These can be assessed statistically to understand the extent of change to that flow regime and for support of hydrological and ecological assessment for ecosystem conservation (Carlisle et al., 2010).

The NFR approach was introduced in aquatic ecology to support the conservation and restoration of ecosystems. It is defined based on five major hydrological characteristics: magnitude, duration, timing, frequency and variability (Richter et al., 1996; Poff et al., 1997), and has recently been widely used in hydrology to analyse the characteristics of streamflow (Poff et al., 1997; Stanford et al., 1996).

Additional to characterising the NFR, the parameters used to describe the NFR support the analysis of change resulting from changing climatological and hydrological characteristics (Poff et al., 1997a; Assani et al., 2010). Anthropogenic activities such as damming, impounding, land use land cover (LULC) change, diversion and abstraction of water and geomorphological change can impact the natural flow regime. Longer-term climate change will also influence hydrological flows (Risbey and Entekhabi, 1996; Sankarasubramanian et al., 2001). These changes will result in changes to hydrological characteristics such as magnitude, duration, timing, frequency and rate of change of flow, and it is important to study these as they provide indication of the wellbeing of the riverine ecosystem (Lytle and Poff, 2004). 
Though the parameters used to define the NFR can be used as an indication of change in a river basin, these do not provide information as to the cause of those changes. Several studies have focused on trends in streamflow characteristics and found the drivers of these changes to include changes to rainfall distributions and patterns, LULC change and human activities such as abstraction, damming, as well as climate change (Adnan and Atkinson, 2011; Rientjes et al., 2011; Van Kirk and Naman, 2008).

While most of these studies focus on flow regime classification (Harris et al., 2000; Krasovkaia, 1997; Gottschalk, 1985; Haines et al., 1988) and restoration of basins impacted by damming, diversion and abstraction (Poff and Zimmerman, 2010), few basins that are as yet undisturbed have been assessed (Poff et al., 1997). This holds equally for basins that are endorheic. Endorheic or closed basins are mostly located in semi-arid to arid climates and often have a terminal lake. The water balance in these terminal lakes is dominated by a high evaporation loss (up to $95-100 \%$ of the inflow) as in Lake Turkana, the Okavango Basin, Lake Chad, the Aral Sea and several other endorheic basins (Crétaux et al., 2010; Wolski et al., 2005; Avery, 2010; Kadukin and Klige, 1991; Yuretich and Cerling, 1983). The water levels in these lakes typically show a highly seasonal variability, with longer-term trends in water levels attributed to changing climate such as changing rainfall patterns, global warming and human influences like LULC change (World Bank, 2006; Magole et al., 2009; Hopson, 1982).

The indicators of hydrologic alteration (IHA) is a software program that can be applied in establishing the flow regime indicators, as well as testing for trends and changes in the flow regime (The Nature Conservancy, 2009). Several options for parametric and non-parametric statistical tests are available in the model. The software analyses 67 hydroecologically important indices using daily streamflow data as input. The IHA have been applied to several basins throughout the world to understand the NFR and to characterise the anthropogenic and climate impacts on water resources of the riverine system and to analyse environmental flows (Maidment and Hersh, 2006). The software can be applied to any type of daily hydrologic data, such as streamflow, river stage, ground water levels, or lake levels. It provides a powerful means for hydrologic data analysis and can be used to summarise long periods of daily hydrologic data into a much more manageable and graphically illustrative set of hydrologic indices (The Nature Conservancy, 2009).

Several researchers have demonstrated how LULC change impacts streamflow. Wooldridge et al. (2001) used a simple model for forest and non-forest and its hydrologic response. Lorup et al. (1998) applied model and statistical tests to investigate the change in hydrological response due to LULC change. LULC change such as the conversion of forest land to crop land resulted in an increase of flow due to reduction of evaporation and infiltration (Fissekis, 2007; Newson, 1997; Rost et al., 2008; Pikounis et al., 2003). Oki et al. (2011) reach a similar conclusion on the impact of LULC change on precipitation, potential evaporation and streamflow by using a simple water balance based on the Budyko equations (Budyko, 1974).

In this paper we apply the natural flow regime approach to the hydrology of the Omo-Ghibe Basin. Through the parameters that characterise the NFR we investigate whether there are changes to the hydrology of the basin, and whether these changes are significant. We analyse the temporal and spatial characteristics of the NFR change using the IHA and identify the driving forces of these changes. Additionally we investigate whether the changes in the basin are related to the change of the water levels in Lake Turkana.

\section{Materials and methods}

\subsection{Study area}

The Omo-Ghibe Basin $\left(79000 \mathrm{~km}^{2}\right)$ has the third largest water potential in Ethiopia, draining the southern Ethiopian highlands and ending in Lake Turkana (Fig. 1a). The basin is largely natural or little disturbed in terms of development, though this is recently starting to change. The basin is characterised by a wide topographic and climate variability. The lower part of the basin is flat and semi-arid to arid, with an elevation of $365 \mathrm{~m}$ at the mouth in Lake Turkana, while the northern upper part is mountainous, with elevations up to $4000 \mathrm{~m}$ and a wet and humid climate. The precipitation and temperature variability is high with high rainfall and lower temperatures in the upstream highlands to lower rainfall and high temperatures in the downstream lowlands.

Lake Turkana, found on the border of Ethiopia and Kenya (Fig. 1a), receives more than $80 \%$ of its water from the Omo-Ghibe Basin (Beadle, 1981). Water from the lake is lost only through evaporation as there is no observed surface outlet, nor any identified subsurface outflow (Survey of Kenya, 1977). Water levels of the lake fluctuate unpredictably (Velpuri et al., 2012; Avery, 2010). The reasons for the lake level fluctuations and in some cases quite drastic changes are currently not well understood.

\subsection{Data availability, quality and selection}

Streamflow. Daily flow data for 32 gauging stations in the Omo-Ghibe River and its tributaries are available with periods of record ranging from 14 to 46 years. For some of these the data quality is, however, poor and has much missing, requiring the data to be carefully screened before application. Five homogeneous regions were determined (see Fig. 1b; the derivation of these five regions will be described in the methodology), and from each region the stations with the best data in terms of quality and record length in excess of 20 years were selected for characterisation of the natural flow regime. For most stations the period of record available spanned from the early 1980s to 2008 and while data from 
(a)

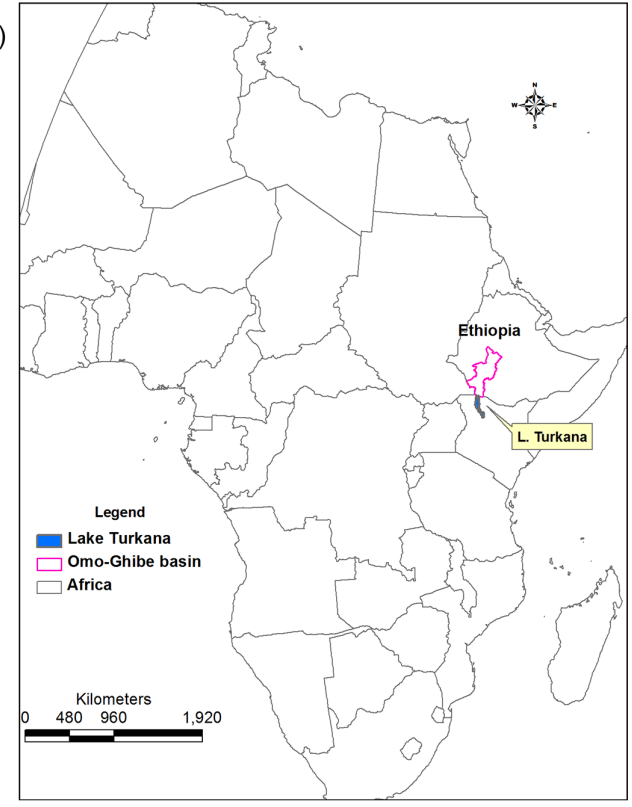

(c)

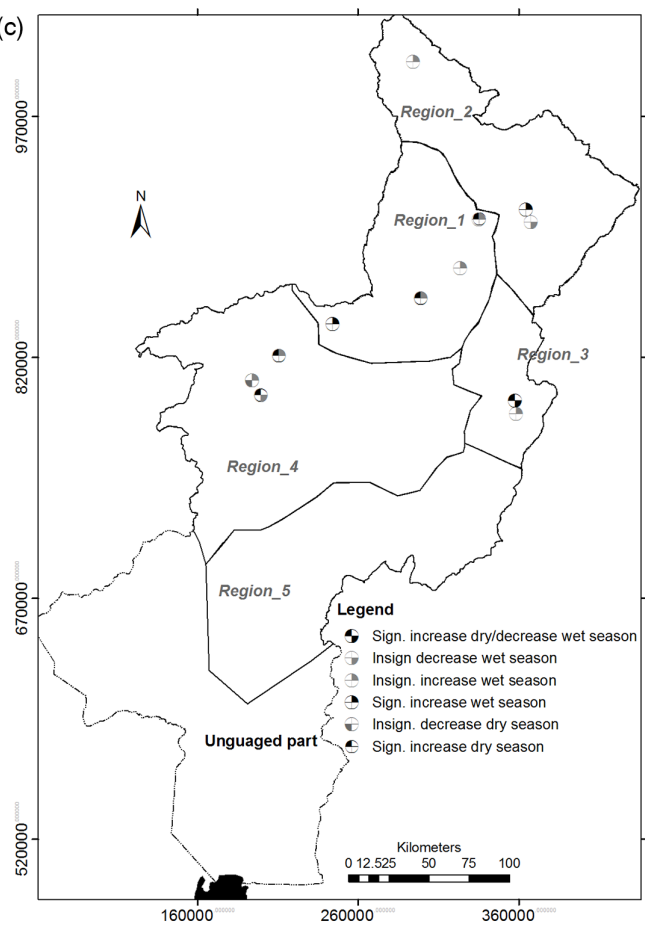

(b)

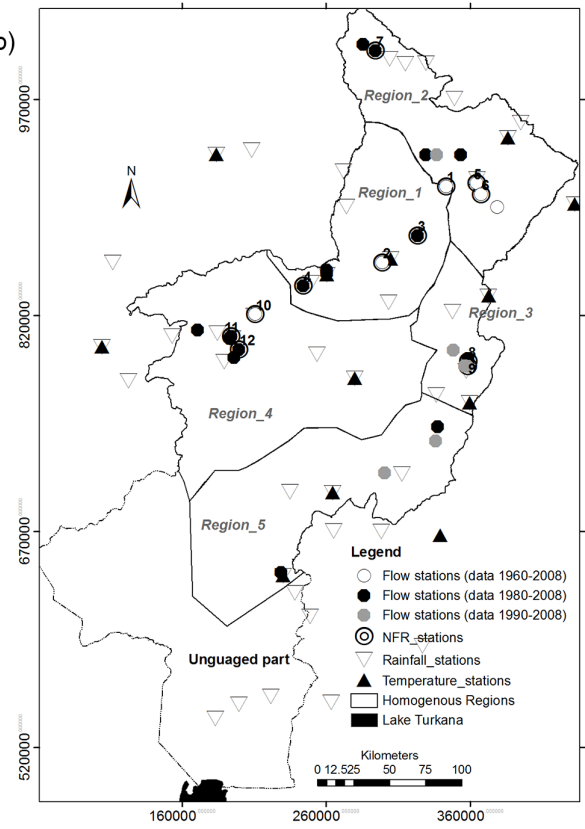

Figure 1. (a) Africa and Ethiopia map (Infoplease, 2012), (b) homogeneous regions and gauging stations based on their length of record year and stations used for NFR analysis, rainfall and temperature stations, (c) NFR trend of dry and wet season ("sign. increase dry" is for significant increase dry season flow; "insign. decrease wet season" is for insignificant decrease wet season flow).

some of the stations spanned from 1960s and 1990s to 2008, we used a common data period from 1982 to 2008 for all stations for the analysis.

Rainfall. Rainfall data are also scarce and the distribution of gauges is uneven, with most stations being in the upstream part of the basin (Fig. 1b). The period of record of many of these stations is good when compared to that of the stream- flow gauges. As with the streamflow data, we have identified stations with good quality data after testing the data for randomness, persistence (independence) and homogeneity. We have sorted the stations based on the available period of record and data quality. In each of the five homogeneous regions, at least four stations with more than 20 years of daily data were selected for the analysis of rainfall variations and 
trends. Most of the rainfall stations had data available from around 1970 through to 2008, though for the station at Areka data were only available from 1988. For this analysis we used data from 1982 to 2008, the same period for which streamflow data were available. We have analysed the quality of data for randomness, independence or persistence (autocorrelation) and consistency both for streamflow and rainfall. We used only those stations which satisfied these criteria and had data without or with only few gaps. Where there were small gaps we used multiple regression to fill missing data using stations from the same homogeneous regions.

Temperature. There are only a few stations that have daily minimum and maximum temperature data in the study area. We have selected 13 stations which results in two to three stations in each homogeneous region that have data with sufficient quality as shown on Fig. 1b. The stations that have 20 or more years of record of both minimum and maximum mean monthly data were used for trend analysis in the time period of 1982-2008.

Lake Turkana water levels. The entire basin that drains into Lake Turkana has an area of about $130860 \mathrm{~km}^{2}$, of which some $57 \%$ is formed by the Omo-Ghibe Basin, Ethiopia. The lake is $250 \mathrm{~km}$ long, has a mean width of $30 \mathrm{~km}$ and a surface area of about $6750 \mathrm{~km}^{2}$. The average depth is $35 \mathrm{~m}$, with a maximum of $115 \mathrm{~m}$. The mean annual temperature at the lake is $30^{\circ} \mathrm{C}$, while the mean annual rainfall is below $255 \mathrm{~mm}$ year $^{-1}$ (Survey of Kenya, 1977). The evaporation rate is $2335 \mathrm{~mm} \mathrm{year}^{-1}$ (Ferguson and Harbott, 1982). As there are no direct observational data of the lake levels available, we used satellite altimetry data obtained from TOPEX/Posiedon, Janson-1, 2 and ENVISAT (Crétaux et al., 2011), with a temporal resolution of 10 days from 1992 to 2012. Even though there is always the possibility of some discrepancy in remotely sensed data unless verified against ground measured, the accuracy of the lake level using the altimetry satellite data is estimated to be in the range of a few centimetres (Birkett, 1995; Mercier et al., 2002). As there are no gauges available on the lake, and stations are virtually absent in the lower part of the basin, the precipitation and temperature data on the lake were taken from the global climate database CRU TS 2.1 (Mitchell and Jones, 2005).

Land use land cover. For the analysis of LULC, we used two sets of land cover data that coincide with the period of record of the streamflow data. These are the global land cover of NASA/NOAA Pathfinder Land (PAL) data set of 19811994 of $1 \mathrm{~km}$ resolution from the Advanced Very High Resolution Radiometer (AVHRR) produced by the University of Maryland Department of Geography (UMDG) (Hansen et al., 1998) and the data set of 2009 with a resolution of $300 \mathrm{~m}$ produced by the European Space Agency (ESA, 2010). These two data sets were modified to be compatible by reprocessing the images based on their legend codes, band values and vegetation classes and physical observations. Both data sets use the same FAO Land Cover Classification System (LCCS) (FAO, 2000). We redefined the
UMDG map to obtain the same naming convention as the 2009 ESA map based on LCCS to identify the changes of LULC between the two periods of time as shown in Fig. 3 . Dominant LULC in each of the five regions in the basin were assessed through GIS analysis of the two maps.

The two original land cover maps differ in sources of satellite data, resolution and processing algorithms. This could lead to erroneous interpretation of land use change between the two periods. A limited validation of the LULC maps was carried out through site visits to areas that remain unchanged in the two maps (water area, bare land and highland forest areas), and a good agreement was found with the classes shown in the two maps, though there were some small differences in area coverage. Additionally, the changes in LULC found in the maps corroborated with changes in land use reported in other basins in Ethiopia (Rientjes et al., 2011).

Potential and actual evapotranspiration (PET and AET). We used MODIS16 (Mu et al., 2011) remotely sensed $1 \mathrm{~km}$ resolution monthly data available for the time period of 2000-2010 in order to investigate possible trends in actual evaporation (AET) and potential evaporation (PET), and to understand whether these reflect the trends found in the temperature data. The MOD16 ET data sets are estimated using $\mathrm{Mu}$ et al. (2011)'s Evapotranspiration (ET) algorithm. The ET algorithm is based on the Penman-Monteith equation (Monteith, 1965). It considers the surface resistance as the effective resistance to evaporation from land surface and transpiration from the plant canopy (ftp://ftp.ntsg.umt.edu/ pub/MODIS/Mirror/MOD16/).

\subsection{Selection of homogeneous regions}

The homogeneous region (HR) concept identifies groups with minimal variation of data within a region, with a larger high spatial variability between regions (Hall and Minns, 2009; Dikbas et al., 2013). There are various approaches for defining regions of hydrologic homogeneity (Borujeni and Sulaiman, 2009; Hosking, 1990; Viglione et al., 2007). We applied conventional moment and L moment (Hosking and Wallis, 1997) methods for regionalisation of HR in the basin. The discordance measure test (Hosking and Wallis, 1993) was used to determine whether the data in each region are homogeneous.

The results of the $\mathrm{L}$ moment parameters $-\mathrm{L}$ coefficient of variation $(t)$, $L$ skewness $\left(t_{3}\right)$ and $L$ kurtosis $\left(t_{4}\right)$ and discordance test $\left(\mathrm{D}_{i}\right)$ - that are used for classification of homogeneous regions are given in Table 1.

By using the average of obtained results of $\mathrm{L}$ moment coefficient variation $(\mathrm{L}-\mathrm{Cv})$, the basin was divided into five homogeneous regions. These do not include the lower ungauged part of the basin (Fig. 1b). The final shape of the homogeneous regions was adjusted based on the watershed flow direction. The identified regions coincide with physical characteristics such as topography, LULC and climate. For example, the northern highlands with intensive agricultural 
Table 1. Homogeneous regions and their L moment and discordance test values with the stations chosen in each region for the analysis of the natural flow regime.

\begin{tabular}{lcccll}
\hline \multirow{2}{*}{ Regions } & \multicolumn{3}{c}{ Regional weighted L-moments } & \multirow{2}{*}{ Selected stations } \\
\cline { 2 - 5 } & $\mathrm{t}$ & $\mathrm{t}_{3}$ & $\mathrm{t}_{4}$ & \multicolumn{1}{c}{$\mathrm{D}_{i}$} & \\
\hline Region 1 & -0.007 & -0.017 & -1.478 & $0.32-1.65$ & Ghibe at Abelti, Ghibe at Asendabo, Bidru, Seka \\
Region 2 & 0.083 & 0.664 & 1.516 & $0.03-2.3$ & Megech, Wabi, Amara \\
Region 3 & -0.031 & -1.673 & 0.249 & $0.22-0.7$ & Ajancho, Shapa \\
Region 4 & 0.053 & 0.368 & -1.050 & $0.22-1.39$ & Gojeb, Dincha, Sheta \\
Region 5 & 0.17 & 1.50 & 3.78 & & Record data less than 20 years \\
\hline
\end{tabular}

and moderate rainfall are defined as one region (region 2), whereas the middle basins with higher forest cover, medium altitude and medium to high rainfall are categorised as within regions 1 and 4. In order to help understand the natural flow variability in each $\mathrm{HR}$, between two and four flow stations with good data quality and a long period of record were selected in each.

\subsection{Natural flow regime analysis and characterising the basin}

The natural flow regime is analysed based on metrics characterising flow magnitude, seasonality, duration, frequency of events and variability (Richter et al., 1996; Poff et al., 1997b). These indices can be used to illustrate ecologically relevant components of the hydrologic regime. From among the 171 hydrological indices currently in use in natural flow regime analysis (Olden and Poff, 2003), we selected 17 indicators. Table 2 lists the selected indicators, divided across the five hydrological characteristics: magnitude (9), timing (2), duration (2), frequency (2) and variability (2).

Daily records for a sufficiently long period are required to reliably calculate the IHA indices. The period of record that is sufficient has been indicated by many authors as being 20 years or more, with up to 35 years of daily data required to account for natural climatic variability for very variable rivers (Richter et al., 1997; Huh et al., 2005). Statistical indices were calculated using indicators of hydrologic alteration (IHA) software for daily flows at 12 gauging stations. The non-parametric Mann-Kendall test was used for detecting the significance of trends found (Mann, 1945; Kendall, 1975 ) at the $5 \%$ two-tail significance level.

\subsection{Driving forces for natural flow regime change}

Drivers that could affect natural flow regimes are mainly climate variability and human activities such as construction of water retention structures (Beavis et al., 1997), deforestation and clearing of land cover, expansion of agricultural land (Masih et al., 2011), urbanisation and catchment change and increased abstraction of water for irrigation and industries, impoundment of water (Alemayehu et al., 2007) and modification of the morphology of the riverine system
(Van Steeter and Pitlick, 1998). In some cases, these variations may change evapotranspiration and the surface energy balance, thereby also affecting the local climate (Cassardo and Jones, 2011). We categorise the driving forces into two major categories - climate variability and anthropogenic change.

\subsubsection{Climate variability}

Climate variability is assessed though monthly rainfall and temperature. Rainfall in the Omo-Ghibe Basin is characterised by a dry season from October to May and a wet season from June to September. The month with the lowest rainfall is January. The rainfall characteristics and variation were analysed using the monthly rainfall data. Trends and significance of trend were analysed using the Mann-Kendall trend analysis. This test applies to serially independent data and was applied only to stations found to be serially uncorrelated in screening the data.

For detecting trends in temperature we selected mean monthly minimum temperature and mean monthly maximum temperature in each homogeneous region. We examined long-term trends of 13 stations with a period of record of more than 20 years. The actual (AET) and potential evapotranspiration (PET) was derived from the remotely sensed MODIS 16 data set (Mu et al., 2011). This was used for trend analysis of evaporation both in the Omo-Ghibe Basin and over Lake Turkana. Use of the MODIS 16 evapotranspiration data involves a combined energy balance and aerodynamic method or Penman-Monteith equation (Monteith, 1965) based on remotely sensed information (Mu et al., 2011).

\subsubsection{Anthropogenic influences}

Although a series of dams has recently been built in the Omo-Ghibe Basin, including the Ghibe I, II and III dams (EEPCO, 2004a, b, 2009), there was no large-scale infrastructure in the basin during the period of record of the data used, and as such the only anthropogenic influences considered are LULC change. For the analysis of LULC, we used two sets of land cover data that coincide with the period of record of the streamflow data. These are the global land cover 
Table 2. 17 Hydrological indices used for characterising the natural flow regime.

\begin{tabular}{|c|c|c|c|}
\hline S.No & Hydrological indices & Category & Description of indices \\
\hline 1 & Annual & \multirow[t]{9}{*}{ Magnitude } & Mean annual flow $\left(\mathrm{m}^{3} \mathrm{~s}^{-1}\right)$ \\
\hline 2 & Dry season & & Mean dry season flow (Nov-May/Jun) $\left(\mathrm{m}^{3} \mathrm{~s}^{-1}\right)$ \\
\hline 3 & Wet season & & Mean rainy season flow (Jun/Jul-Oct) $\left(\mathrm{m}^{3} \mathrm{~s}^{-1}\right)$ \\
\hline 4 & 7-day minimum flow & & Annual 7-day minimum flow mean $\left(\mathrm{m}^{3} \mathrm{~s}^{-1}\right)$ \\
\hline 5 & 7-day maximum & & Annual 7-day maximum flow mean $\left(\mathrm{m}^{3} \mathrm{~s}^{-1}\right)$ \\
\hline 6 & Base flow Index & & 7 day minimum flow/mean flow for year (dimensionless) \\
\hline 7 & FDC (annual) & & Annual flow duration curve $\left(\mathrm{m}^{3} \mathrm{~s}^{-1}\right)$ \\
\hline 8 & FDC (dry season) & & Driest month/s flow duration curve $\left(\mathrm{m}^{3} \mathrm{~s}^{-1}\right)$ \\
\hline 9 & FDC (wet season) & & Wettest month/s flow duration curve $\left(\mathrm{m}^{3} \mathrm{~s}^{-1}\right)$ \\
\hline 10 & Date of minimum flow & \multirow[t]{2}{*}{ Timing } & Julian date of annual 1-day minimum flow (days) \\
\hline 11 & Date of maximum flow & & Julian date of annual 1-day maximum flow (days) \\
\hline 12 & Extreme low flow duration & \multirow[t]{2}{*}{ Duration } & Number of days of extreme low flow in a year (days) \\
\hline 13 & High flow duration & & Number of days of high flow in a year (days year ${ }^{-1}$ ) \\
\hline 14 & Extreme low flow frequency & \multirow[t]{2}{*}{ Frequency } & Frequency of extreme low flow in a year \\
\hline 15 & High flow frequency & & Frequency of high flow in a year \\
\hline 16 & Low pulse count & \multirow[t]{2}{*}{ Variability } & The number of low pulses in a year (events year ${ }^{-1}$ ) \\
\hline 17 & High pulse count & & The number of high pulses in a year (events year ${ }^{-1}$ ) \\
\hline
\end{tabular}

of NASA/NOAA Pathfinder Land (PAL) data set of 19811994 of $1 \mathrm{~km}$ resolution from the Advanced Very High Resolution Radiometer (AVHRR) produced by the University of Maryland Department of Geography (UMDG) (Hansen et al., 1998) hereafter referred to as the 1990s LULC map and the data set of 2009 with a resolution of $300 \mathrm{~m}$ produced by the European Space Agency (ESA, 2010), hereafter referred to as the 2009 LULC map. These two data sets were modified to be compatible by reprocessing the images based on their legend codes, band values and vegetation classes and physical observations. Both data sets use the same FAO Land Cover Classification System (LCCS) (FAO, 2000). We redefined the UMDG map to obtain the same naming convention as the 2009 ESA map based on LCCS to identify the changes of LULC between the two periods of time as shown in Fig. 3 . Dominant LULC in each of the five regions in the basin were assessed through GIS analysis of the two maps.

\section{Results}

\subsection{Natural flow regime change}

The natural flow regime in the Omo-Ghibe Basin was analysed based on the daily flow data for the 20-30 years of available data at each of the 12 selected stations. These stations are distributed spatially across the basin in four homogeneous regions. There are no stations with a sufficiently long data record in region 5 (in a lower part of the basin, see Fig. 1b) while in the lowest part of the basin there are no stations at all. These two regions were therefore not consid- ered in the analysis. We calculated 17 indices at each of the stations and assessed the presence of trend using Sen's slope estimator (Sen, 1968).

Table 3 provides an overview of the number of streamflow stations from the 12 analysed at which an increasing or a decreasing trend was detected (columns (2) and (4) respectively), whereas, columns (3) and (5) show the number of stations at which the increasing or decreasing trend was significant at the $5 \%$ level.

The first nine indices in Table 3 reflect changes to the magnitude of flows in the basin. For most of the stations the general trend indicates that these are increasing, though this increase is only significant at selected stations. Most of the indices concerned with low flows (dry season mean, 7day minimum flow, base flow index) equally show a positive trend. This positive trend is, however, less apparent for the high flow indices (wet season flow, 7-day max flow), with the number of stations showing positive trends balanced by the number of stations with a decreasing trend, and only very few stations showing trend at the $5 \%$ significance level. This is also reflected in the flow duration curves shown in Fig. 4. These show the annual FDC, as well as the FDC for the dry and wet months. These curves are developed for two 13-year periods (1982-1995, and 1996-2008), to analyse whether there are any clear changes to the distribution between the two periods, and whether these corroborate trends found in other indices. Overall, these results suggest that the dry season and annual flows are higher in the second period for the majority of the stations, while the wet season flows remain almost the same. 
Table 3. Hydrological indices analysed at 12 stations and the number of stations that show a generally increasing or decreasing trend, as well as the number of stations at which the trend is significant at the $\alpha=5 \%$.

\begin{tabular}{|c|c|c|c|c|c|}
\hline & (1) & (2) & (3) & (4) & (5) \\
\hline S.No. & Hydrological indices & $\begin{array}{c}\text { General } \\
\text { increasing }\end{array}$ & $\begin{array}{l}\text { Significant } \\
\text { increasing } \\
\text { at } \alpha=5 \%\end{array}$ & $\begin{array}{c}\text { General } \\
\text { decreasing }\end{array}$ & $\begin{array}{l}\text { Significant } \\
\text { increasing } \\
\text { at } \alpha=5 \%\end{array}$ \\
\hline \multicolumn{6}{|c|}{ Magnitude } \\
\hline 1 & Annual flow & 8 & 2 & 4 & 1 \\
\hline 2 & Dry season flow & 9 & 2 & 3 & 0 \\
\hline 3 & Wet season flow & 6 & 2 & 6 & 1 \\
\hline 4 & 7-day minimum flow & 7 & 4 & 4 & 1 \\
\hline 5 & 7-day maximum flow & 8 & 2 & 4 & 2 \\
\hline 6 & Base flow index & 8 & 5 & 4 & 0 \\
\hline 7 & FDC (annual) & 8 & 7 & 4 & 3 \\
\hline 8 & FDC (dry season) & 6 & 5 & 6 & 4 \\
\hline 9 & FDC (wet season) & 6 & 3 & 6 & 3 \\
\hline \multicolumn{6}{|c|}{ Timing } \\
\hline 10 & Date of minimum flow & 3 & 0 & 9 & 2 \\
\hline 11 & Date of maximum flow & 2 & 0 & 9 & 0 \\
\hline \multicolumn{6}{|c|}{ Duration } \\
\hline 12 & Extreme low flow duration & 2 & 0 & 9 & 0 \\
\hline 13 & High flow duration & 4 & 1 & 7 & 2 \\
\hline \multicolumn{6}{|c|}{ Frequency } \\
\hline 14 & Extreme low flow frequency & 2 & 1 & 7 & 4 \\
\hline 15 & High flow frequency & 5 & 1 & 2 & 1 \\
\hline \multicolumn{6}{|c|}{ Flow variability } \\
\hline 16 & Low pulse count & 3 & 0 & 6 & 2 \\
\hline 17 & High pulse count & 5 & 2 & 2 & 0 \\
\hline
\end{tabular}

The following two indices consider the timing of the high and low flow peaks. While there is some suggestion in the general trend that these are decreasing, which means that they are occurring earlier in the year, these trends are found to be significant at only two stations, suggesting little change in the seasonality of the flows in the basin.

The hydrologic characteristic of duration is represented by two indices (duration of low and high flows). For these indices, the majority of the stations show a decreasing trend. This would indicate that the duration of both high flows as of low flows is getting shorter, but again the trend is observed to be significant at only very few stations.

Indicators describing frequency include the frequency of extreme low flows and high flows. The extreme low flow frequency (i.e. the recurrence interval of extreme low flows) shows a significantly decreasing trend in most stations, while for high flow frequency, the trend was found to be insignificant at the majority of the stations. This is consistent with the observation that dry season flows are increasing, while wet season flows are largely unchanged. A similar pattern can be seen in the hydrological indices of flow, represented by the low and high pulse counts. The low flow pulse count shows a decreasing trend and the latter a positive trend, though in this case both trends are insignificant.

The results show that changes in the NFR are significant only for the indices of magnitude, though the change was only significant at selected stations, in particular those in regions 1 and 4 . In the majority of the stations the changes suggest an increase in the dry season flow, and consequent increase in annual flows. Trends are also shown for other indices of timing, duration, frequency and variability, but these were found to be significant at very few stations.

\subsection{Changes to precipitation, temperature and evaporation}

The climatic data of precipitation and temperature in the study area were analysed for trend over the range of 1982 2008 at a monthly timescale. Change to rainfall patterns and magnitude is one of the possible drivers of the change to the natural flow regime. We analysed possible changes of rainfall 
patterns and magnitude for two seasons: the wet season or "Kiremet", which is the major rainy season for most stations from June to September (in region 4, this is slightly shifted and is taken as being from May to September) and the dry season which includes the second rainy season or "Belg" and the remaining months. Twenty-one rainfall stations with a data record of sufficient length and quality were selected in the analysis (Table 4). In none of the four regions was a dominant trend found to be significant, except for two stations in regions 2 and 3, which both showed a decreasing trend. A shift of the timing of the main rainfall hyetograph was also not found.

The other climatic variable with an influence on the basin hydrology is temperature. The potential and actual evapotranspiration rates are highly influenced by temperature. We used 13 stations with sufficient records of monthly mean minimum, maximum and mean monthly temperature from each region in the upstream catchments. Results in Table 5 show that for almost all except two stations a positive trend for maximum, minimum and mean monthly temperature was found. In addition, these trends are significant in a majority of the stations.

From the CRU TS 2.1 global climate database (http://cru. csi.cgiar.org), the rainfall and temperature data over Lake Turkana have been analysed for trends from 1981 to 2002 at the monthly scale, showing a significantly positive trend of the mean, minimum and maximum temperature at the $5 \%$ significance level.

MODIS remotely sensed data were used to investigate possible trends in actual evaporation (AET) and potential evaporation (PET), and to understand if these reflect the trends found in the temperature data. Although these data have not been validated against observed data in the basin due to the lack of measurements from for example flux towers (Trambauer et al., 2014), they can be applied for detecting trends. We investigate the presence of trends in the five homogeneous regions and downstream ungauged region using monthly values of remotely sensed AET and PET data from 2000 to 2011. These show a decreasing trend for PET, though this is significant only in regions 2 and 4 . The AET shows a positive trend in regions 2 and 5 as well as in the ungauged part of the basin though this trend is not found to be significant. A decreasing trend is found in the middle part of the basin (regions 1, 3, 4) and is significant in regions 1 and 4 as shown in Table 6.

The dryness index $(\mathrm{DI}=\mathrm{PET} / P)$ and the evaporative in$\operatorname{dex}(\mathrm{EI}=\mathrm{AET} / P)$ were calculated using the mean annual value of PET, AET and precipitation $(P)\left(\mathrm{mm} \mathrm{year}^{-1}\right)$ calculated at 70 spatially distributed points that represent all LULC. PET and AET were sampled from the $1 \mathrm{~km}^{2}$ MODIS images, while values for $P$ were determined using inverse distance weighting. The spatially distributed points were subsequently averaged over each homogeneous region. These show that most of the regions are water limited (i.e. DI > 1.0). Only region 4 and to some extent region 1 tend towards

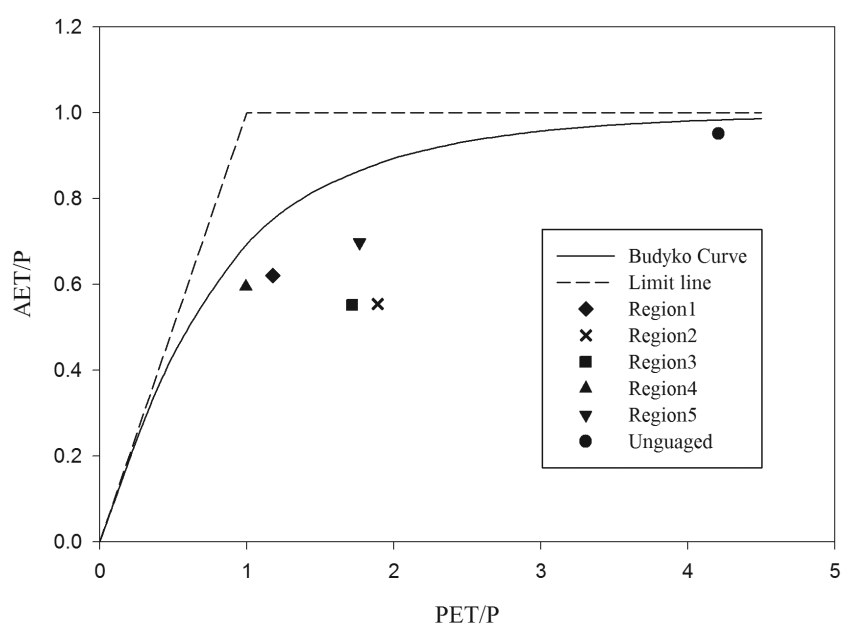

Figure 2. The average aridity index $(\mathrm{PET} / P)$ and the evaporative index $(\mathrm{AET} / P)$ of the study area for the five homogeneous regions and ungauged part of the basin compared to the Budyko Curve (Budyko, 1974).

being energy limited, as shown in Fig. 2. Based on the aridity index (AI $=P / \mathrm{PET}$; UNEP, 1997), regions 1 and 4 are categorised as humid, while regions 2, 3 and 5 are categorised as dry sub-humid. The downstream ungauged part of the basin is categorised as semi-arid.

The positive trend in the temperature clearly would be expected to have an influence on evapotranspiration and consequently on streamflow, but other factors like LULC change (canopy resistance, leaf area and interception) make this a complex phenomenon and the overall impacts depend on dominant change in the types of land use (Zhang et al., 2001; Yang et al., 2012).

The trend found in AET does not always reflect the positive trend in temperature, such as in regions 1 and 4, despite the importance of temperature to evaporation, which would suggest that it may depend more on the dominant LULC change.

\subsection{Change detection of LULC}

LULC in the basin were analysed for two periods using the available remotely sensed LULC maps from the 1990s and 2009. These show that there have indeed been significant changes in the LULC, though these changes differ across the basin. In all regions, forest land (FL), woodland (WL) woody grassland (WG) and shrubland (SL) decreased, except in regions 2 and 3 where the FL is increasing. This increase in FL is, however, offset by the decrease in WL and WG. In contrast, cropland (CL), grassland (GL) and bare land (BL) increased almost in all of the regions as shown on Fig. 3a, b and Table 7. Overall, the FL, WL WG and SL decreased by $53 \%$, while the area of CL and GL increased by $83 \%$. 
Table 4. Rainfall trend (Sens's slope) in the dry and wet season and the significance level test ( $z$ and $p$ ) for trends in the five homogeneous regions with the $\alpha=5 \%$ significance level for 21 stations and Lake Turkana. Bold numbers are numbers which show a significant trend at a $5 \%$ significant level.



* This is a monthly trend not seasonal.


Figure 3. Comparison of LULC maps of the study area for (a) the 1990s and (b) 2009.

LULC change from FL, WL, WG and SL to CL and GL would be expected to contribute to reduced interception, less infiltration, lower actual evaporation and hence result in higher runoff. The trends found in the IHA indices, such as for the 7-day minimum flow, as well as changes to the dry season FDC between the first and second parts of the periods analysed reflect this increase in runoff. This would suggest the dominance of LULC change in the changing distribution of runoff over changes due to the climate effect. 

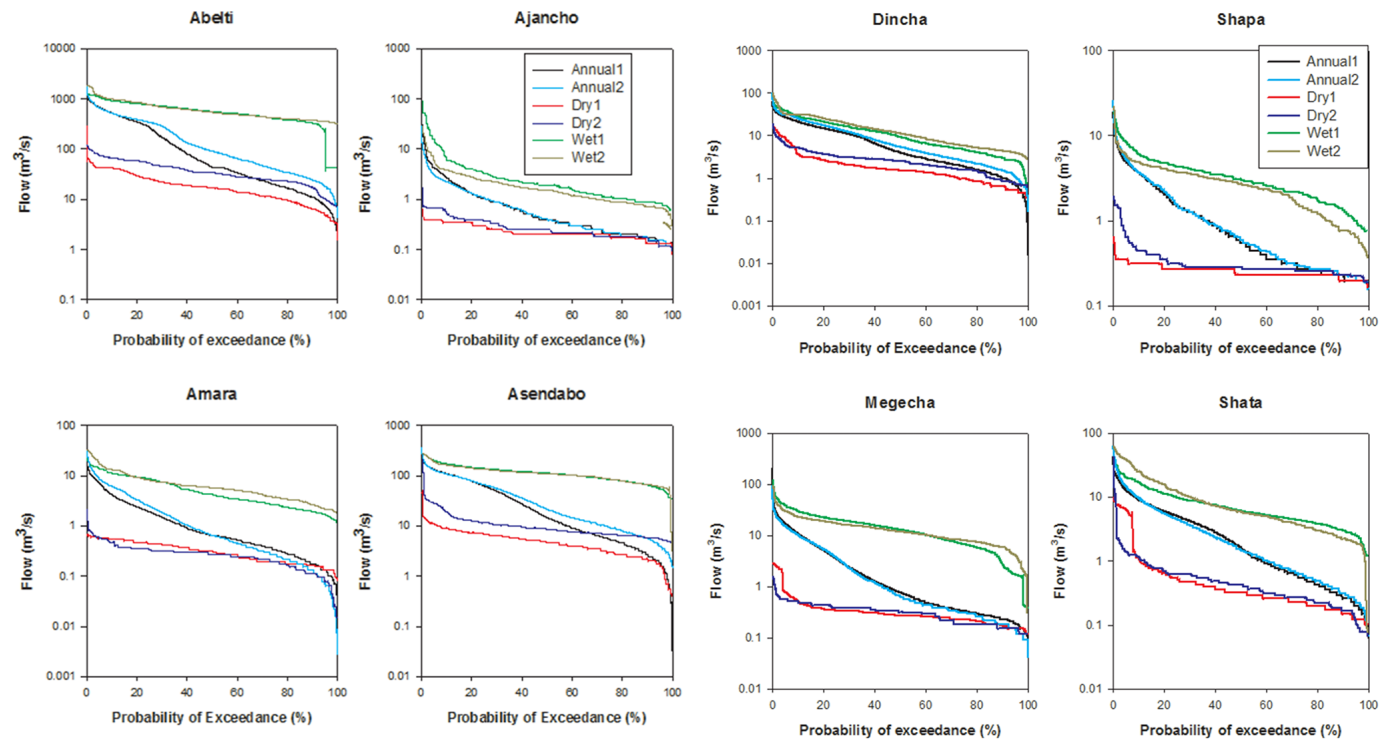

Figure 4. Flow duration curves for gauging stations used in the analysis, for annual, dry and wet months change over two periods before 1995 (annual 1) and after 1995 (annual 2).

Table 5. Monthly minimum, maximum and mean temperature trends (Sen's slope), and its significance at $\alpha=5 \%$ significance level test $(z$ and $p$ ) for 13 stations and on Lake Turkana in the study area. Bold numbers are numbers which show a significant trend at a $5 \%$ significant level.

\begin{tabular}{|c|c|c|c|c|c|c|c|c|c|c|}
\hline & \multirow[t]{2}{*}{$\begin{array}{l}\text { Selected } \\
\text { stations }\end{array}$} & \multicolumn{3}{|c|}{$\begin{array}{l}\text { Maximum } \\
\text { temperature }\end{array}$} & \multicolumn{3}{|c|}{$\begin{array}{l}\text { Minimum } \\
\text { temperature }\end{array}$} & \multicolumn{3}{|c|}{$\begin{array}{l}\text { Mean monthly } \\
\text { temperature }\end{array}$} \\
\hline & & Sen's slope & $z$ & $p$ & Sen's slope & $z$ & $p$ & Sen's slope & $z$ & $p$ \\
\hline \multirow[t]{2}{*}{ Region 1} & Jimma & 0.054 & 3.86 & 0.0001 & 0.026 & 4.18 & $<0.0001$ & 0.036 & 4.93 & $<0.0001$ \\
\hline & Asendabo & -0.023 & -1.94 & 0.053 & 0.076 & 3.81 & 0.0001 & 0.022 & 2.71 & 0.007 \\
\hline \multirow[t]{3}{*}{ Region 2} & Welkite & 0.25 & 5.09 & $<0.0001$ & 0.056 & 3.36 & 0.0008 & 0.153 & 5.14 & $<0.0001$ \\
\hline & Weliso & 0.029 & 3.40 & 0.0007 & 0.076 & 3.49 & 0.0005 & 0.059 & 3.78 & 0.00016 \\
\hline & Butajira & 0.08 & 4.22 & $<0.0001$ & 0.025 & 0.00 & 1.000 & 0.046 & 1.8 & 0.056 \\
\hline \multirow[t]{2}{*}{ Region 3} & Hosana & -0.013 & -1.56 & 0.119 & 0.063 & 1.38 & 0.168 & 0.012 & 2.48 & 0.013 \\
\hline & Walaita & 0.25 & 3.4 & 0.001 & 0.069 & 4.0 & 0.0001 & 0.072 & 4.19 & $<0.0001$ \\
\hline \multirow[t]{3}{*}{ Region 4} & Sokeru & 0.015 & 0.84 & 0.399 & 0.026 & 1 & 0.315 & 0.007 & 1.11 & 0.268 \\
\hline & Chira & 0.282 & 2.77 & 0.006 & 0.053 & 3.89 & 0.0001 & 0.053 & 3.42 & 0.00062 \\
\hline & Tepi & 0.024 & 2.90 & 0.0037 & -0.04 & -1.33 & 0.184 & -0.006 & -0.73 & 0.464 \\
\hline \multirow[t]{3}{*}{ Region 5} & Jinka & 0.026 & 3.48 & 0.0005 & 0.024 & 2.04 & 0.04 & 0.023 & 4.54 & $<0.0001$ \\
\hline & Sawla & 0.045 & 1.80 & 0.071 & 0.025 & 1.32 & 0.186 & 0.022 & 1.63 & 0.104 \\
\hline & A. Minch & 0.016 & 2.16 & 0.031 & -0.05 & -2.46 & 0.014 & -0.014 & -1.68 & 0.093 \\
\hline \multicolumn{2}{|c|}{ Lake Turkana } & 0.08 & 2.50 & 0.01 & 0.29 & 2.04 & 0.04 & 0.17 & 2.40 & 0.02 \\
\hline
\end{tabular}

\subsection{Lake Turkana water levels trend}

We analysed the water levels in Lake Turkana (LT) using the satellite altimetry data that was available at monthly time steps from October 1992 to May 2012 (Fig. 5). Over the whole period a significantly positive trend of lake levels can be seen, with levels at the end of the period some
$2 \mathrm{~m}$ above those at the beginning. Seasonal and interannual peaks and troughs in the lake level across the years can be seen. The maximum level is reached mostly in the months of November-January, followed by a rapid drawdown to the lowest level in February-May. In rare cases the minimum level occurs in June or even in July. In the period considered, the maximum level the lake reached was $365.21 \mathrm{~m}$ in 
Table 6. Remotely sensed data from MODIS16 actual and potential evapotranspiration trend and significance test at $5 \%$ in the homogeneous regions of the study area and climate class based on UNEP 1997 aridity index (UNEP, 1997). Bold numbers are numbers which show a significant trend at a $5 \%$ significant level.

\begin{tabular}{|c|c|c|c|c|c|c|}
\hline & \multicolumn{2}{|c|}{ Actual evapotranspiration } & \multicolumn{2}{|c|}{ Potential evapotranspiration } & \multirow[t]{2}{*}{ Aridity index $(p / \mathrm{PET})$} & \multirow[t]{2}{*}{ Climate class } \\
\hline & $z$ & $p$ & $z$ & $p$ & & \\
\hline Region 1 & -2.2 & 0.03 & -1.27 & 0.18 & 0.85 & Humid \\
\hline Region 2 & 0.89 & 0.42 & -1.99 & 0.048 & 0.53 & Dry sub-humid \\
\hline Region 3 & -1.3 & 0.17 & -0.76 & 0.47 & 0.58 & Dry sub-humid \\
\hline Region 4 & -2.9 & 0.04 & -2.63 & 0.006 & 1.01 & Humid \\
\hline Region 5 & 0.15 & 0.81 & -0.76 & 0.47 & 0.57 & Dry sub-humid \\
\hline Ungauged & 1.56 & 0.06 & -0.71 & 0.49 & 0.24 & Semi-arid \\
\hline
\end{tabular}

Table 7. LULC changes in the five homogeneous regions of the basin.

\begin{tabular}{llccc}
\hline & Land cover type & $\begin{array}{c}1990 \text { s area } \\
(1000 \text { ha })\end{array}$ & $\begin{array}{c}2009 \text { area } \\
(1000 \text { ha })\end{array}$ & $\begin{array}{c}\text { Area change } \\
(\%)\end{array}$ \\
\hline \multirow{2}{*}{ Region 1} & Forest, woodland and woody grassland and shrubland & 608 & 161 & -73 \\
& Grassland and cropland & 362 & 809 & 123 \\
\hline \multirow{2}{*}{ Region 2 } & Forest, woodland and woody grassland and shrubland & 409 & 118 & -71 \\
& Grassland and cropland & 771 & 1062 & 38 \\
\hline \multirow{2}{*}{ Region 3 } & Forest, woodland and woody grassland and shrubland & 201 & 115 & -43 \\
& Grassland and cropland & 241 & 327 & 36 \\
\hline \multirow{2}{*}{ Region 4} & Forest, woodland and woody grassland and shrubland & 1521 & 541 & -64 \\
& Grassland and cropland & 376 & 1356 & 261 \\
\hline \multirow{2}{*}{ Region 5 } & Forest, woodland and woody grassland and shrubland & 856 & 740 & -14 \\
& Grassland and cropland & 560 & 676 & 21 \\
\hline & Total area (ha) & 5905 & 5906 & -53 \\
& Total forest, woodland, woody grassland, shrubland & 3595 & 1676 & 83 \\
\hline
\end{tabular}

November 1998. The lowest level was $360.47 \mathrm{~m}$ in February 1996. There was a dramatic increase from the low level of $361.47 \mathrm{~m}$ in March 1997 to a peak level of $365.21 \mathrm{~m}$ in November 1998. From the peaks of 1998 to the lowest level of June 2006 a continuous downward trend with some seasonal fluctuation is observed. The maximum drop of $4.21 \mathrm{~m}$ is observed between late 1992 and 2011.

The delay between the peak rainfall in the upper catchments and the peak flow at the mouth of the lake is 1 to 2 months, with a further 3 to 5 months delay between the peak flow and the peak lake level. Peak rainfall occurs from July to September, peak flows in August-October, while peak lake levels are found in November-January. After adjusting for these delays, a clear correspondence between the variation of rainfall, inflow and lake level is found as shown in Fig. 6, despite the decreasing trend of the lake levels in this period - though not of inflow. To understand the lake level variation and rainfall in the basin, we calculated cumulative rainfall departure (CRD), which shows the total rainfall magnitude above or below the mean. It is calculated as the cumulative value of each month's difference from the mean value of the data. The flows at the mouth shown in the figure were calculated using a simple water balance model (Abera, 2012), and though these modelled results appear to overestimate real flows, the correspondence of the pattern of the inflows to the variation of lake levels is clear. However, the declining lake level was not matched by the inflow trend (Fig. 6) - rather, in this period there is observed a lesser value in consecutive seasons, or declining CRD, as shown in Fig. 5. The relatively short period for which the results of Abera's (2012) model were available meant that a reliable analysis of trends could not be carried out.

In order to help us understand the lake level change and the driving forces, we categorised the period of investigation into four distinct times of remarkable lake level changes and overlay the CRD as shown in Fig. 5. The first period is from the end of 1992 to mid-1996, during which the lake reached its lowest level $(360.47 \mathrm{~m})$. The peak during the period was only about $362 \mathrm{~m}$. In this period, consecutive decline of CRD (November 1993-June 1997) as shown in Fig. 5 and low 


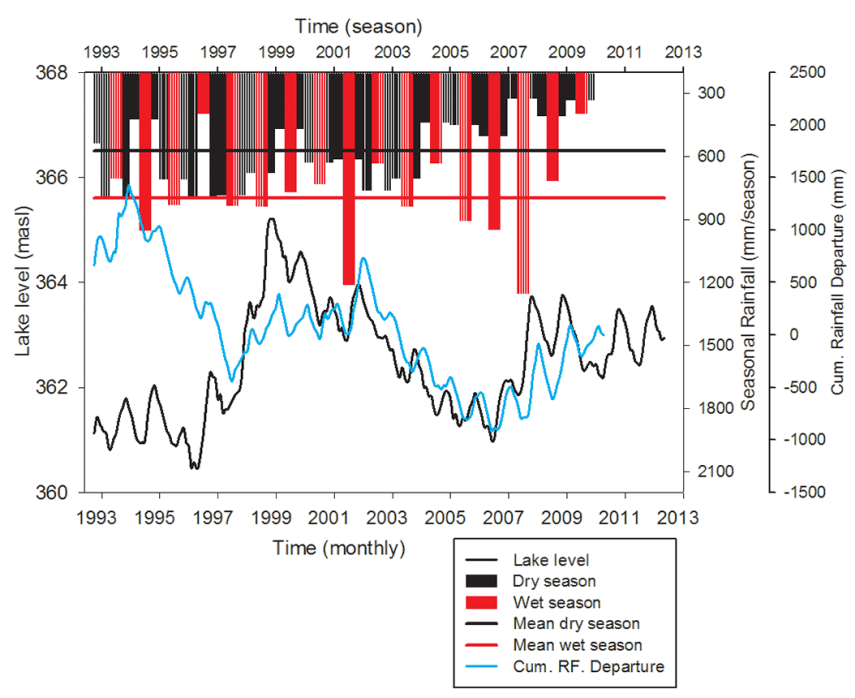

Figure 5. Lake Turkana water level fluctuation from late 1992 to early 2012 derived from altimetry data and Omo-Ghibe Basin areal rainfall. Areal rainfall is averaged for the dry (black) and wet season (red), with the mean rainfall for each season shown as a horizontal black/red line for the dry season and wet season respectively. The areal monthly cumulative rainfall departure in the Omo-Ghibe Basin is shown in blue.

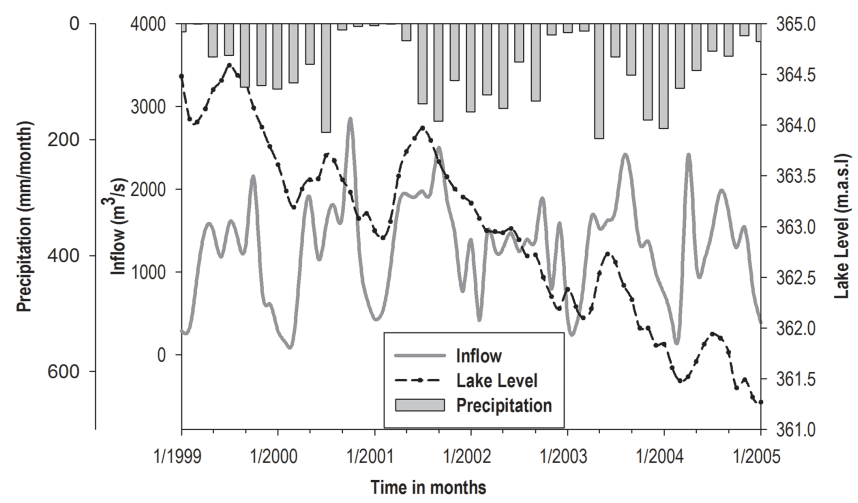

Figure 6. Comparison of lake level variation versus Omo-Ghibe inflow (Abera, 2012) and average areal precipitation on the basin.

rainfall below the basin average was found in the years 1994 and 1995 in almost all stations in the upstream basin, as well as on the lake (where rainfall was obtained from the CRU data set).

The second period is from mid-1996 to end of 2001; a period in which the lake level reached the maximum level $(365.21 \mathrm{~m})$, and for which the lowest level was $361.58 \mathrm{~m}$. High rainfall was recorded in consecutive dry and wet seasons (longer and continuously increasing CRD as shown in Fig. 5 in the period of July 1997-February 1999 which results in the peak lake levels of 1998. This was followed by low rainfall and a drop of consecutive CRD from early 1999 to the end of 2001) with the lake level declining from the peak of 1998 to a low level in 2003 with some seasonal fluc- tuations, and a short rise after the large wet season rainfall of 2001 (rise of CRD in 2001). A high-rainfall event across East Africa in 1997-1998 that caused a lot of damage and resulted in record river flows and lake levels in the region (Anyamba, 2002; Conway, 2002) likely contributed to the record high lake levels in 1998.

The third period from early 2002 to mid-2006 shows a drastic decline of the lake levels, reaching a low of $360.99 \mathrm{~m}$, and a peak of only $362.73 \mathrm{~m}$. There was a recorded drought in 2004-2005 in the region (Ebei et al., 2008), reflected also in the consecutive low dry and wet seasons rainfall (Fig. 5) and the CRD is also declining from early 2002 to mid-2006 (Fig. 5).

The fourth period is from mid-2006 to mid-2012 during which the lake level rises again from the low period to peak at $363.75 \mathrm{~m}$, with a low for the period of $361.85 \mathrm{~m}$. In this period the CRD is rising in a consecutive manner from mid2006 to the end of 2009 (Fig. 5). The beginning of the rise of lake level coincides with the August 2006 floods in the Omo Basin which caused many deaths and displaced many people at the mouth of the river in Lake Turkana. Additionally, the July 2007 high flows of Omo (EEPCO, 2009) contributed to the rise.

From these four periods as well as from the historical records of lake levels (Conway, 2002), the fluctuation of the Lake Turkana water levels can be seen to be seasonal with multiannual trends. The water balance of Lake Turkana constitutes inflow to the lake from the major rivers (like the Omo-Ghibe, Turkwel and Kerio), rainfall on the lake, evaporation from the lake and groundwater inflow and outflow. The inflow to the lake is dominated by the Omo-Ghibe Basin (80-90\%) (Beadle, 1981), with the other two large tributaries being intermittent and contributing significantly less. Mean annual rainfall on the lake is $258 \mathrm{~mm}_{\text {year }}{ }^{-1}$ from CRU data analysis and shows a positive trend. Velpuri et al. (2012) show that the rainfall on Lake Turkana is less than $30 \%$ of evaporation loss, with the evaporation showing a positive trend, thus confirming that the two main components in the water balance of the lake are the inflow from the Omo-Ghibe Basin and evaporation from the lake.

\section{Discussion}

\subsection{Changes to the flow regime in the Omo-Ghibe Basin}

The natural flow regime (NFR) was analysed at selected hydrological stations with respect to 17 hydrological indices for hydrological characteristics of magnitude, timing, duration, frequency and flow variability. Significant changes (regions 1 and 4) in these indices in time were observed primarily for indices describing the magnitude of flows. For other variables including those for timing, duration, frequency and variability some indications of trend were observed, but with little statistical evidence at the $5 \%$ significance level. The positive trends in the indices of magnitude were found mainly in 
those describing low (dry season) flows, with high (wet season) flows displaying very little significant trend. Of the indices of frequency, only that for extreme low flow frequency showed a significantly decreasing trend at four stations (stations $1,2,10,12)$. This trend complements the increase in the magnitude of dry season flows. The trends found in the magnitude of the dry season flows mirror changes found in several other basins in Ethiopia, including the Nile Basin and the Didessa Basin (Sayed, 2008; Sima, 2011).

Using an average of all stations in Ethiopia, Cheung et al. (2008) show a significant decrease of rainfall in the Kiremet season (main rainy season), with an (insignificant) increase for the Belg season (minor rainy season) in the Omo-Ghibe Basin. While such increases of rainfall during the Belg season could contribute to the increase in dry season flows, the trend in rainfall over the Omo-Ghibe Basin was not found to be significant in this study, for either of the rainy seasons. However, there were high- and low-rainfall seasons which led to longer and consecutive increase/decrease of CRD, which were closely matched by seasonal lake level fluctuations (Fig. 5). Significant trends were only found at three stations of the 21 evaluated, though this trend was mainly decreasing, and increasing only for the wet season at the station at Butajira. Trends for mean monthly, minimum and maximum monthly temperature were found to be significant in all except a few stations, as reported also for the whole of Ethiopia by the Climate Change National Adaptation Programme of Action (NAPA) of Ethiopia (FDRE National Meteorological Agency, 2007; Ogallo, 2009). Despite this, trends in potential evaporation (PET) and actual evaporation (AET) using remotely sensed data from MODIS were found to contradict what would be expected from the temperature trend. PET is found to be decreasing in all regions, although this is significant only in regions 2 and 4. AET is shown to be significantly decreasing in regions 1 and 4 . There are many governing factors to affect PET and AET besides temperature change. In humid areas, LULC has a more dominant effect on evapotranspiration than does temperature change, but in arid regions climate has a greater effect than LULC change as revealed by many researchers (Yang et al., 2009; Tomer and Schilling, 2009).

LULC change was examined for two distinct periods using land use maps of the 1990s and 2009. Even allowing for some expected inaccuracy due to different LULC map we used, the changes found were significant and expected as the basin is dominantly inhabited by an increasing population of pastoralist and farming society, with a need of grass and farming areas (MoWR, 1996; CSA, 2007). This result was broadly similar to those found in several other studies in Ethiopia (Rientjes et al., 2011; Emiru et al., 2012). Forested land (FL), woodland (WL), woody grasslands (WG) and shrub lands (SL) dramatically declined by some 14$73 \%$, while grasslands (GL) and croplands (CL) increased in the range of $21-261 \%$, depending on the region in the study area. These LULC changes clearly have a strong influ- ence on the hydrologic response of the basin (Nejadhashemi et al., 2011; Schilling et al., 2008; Mao and Cherkauer, 2009; Siriwardena et al., 2006). The changes in LULC observed could be expected to trigger quicker surface runoff and decrease infiltration, thus leading to increased surface runoff during the high flow (wet) season, though these changes were less clear. The change in the hydrological response that leads to the observed increase in the dry season flows can, however, be explained by the lower AET and interception resulting from the decrease of area of FL, WL and WG. Additionally, CL and GL are seasonal and have shallow root depths compared to FL and WL and WG (Fissekis, 2007; Poff et al., 2006; Rientjes et al., 2011) again resulting in increased runoff mainly in the dry season. The increase in dry season flows was found to be significant mainly in the more humid regions in the basin (regions 1 and 4, with an aridity index close to 1), in contrast to the more arid regions of the basin which are closer to being energy limited and thus more sensitive to small changes in the water balance caused by the LULC changes. In the drier sub-humid regions (regions 2, 3 and 5), the variability in the climatic drivers would be expected to be more influential than LULC change (Yang et al., 2009).

Spatial variation of natural flow regime was observed in the basin. Humid regions 1 and 4, which were dominated by FL, WL, WG and SL, have shown more significant changes in low-flow magnitudes compared to dry sub-humid regions 2, 3 and 5 dominated by CL and GL. In regions 1 and 4, FL, WL, WG and SL decreased by $64-73 \%$, but CL and GL increased by $123-261 \%$, whereas in regions 2,3 and 5, CL and GL increased by ranges of 21-38\%.

\subsection{Changes to the water levels in Lake Turkana}

As an endorheic lake, the levels in Lake Turkana depend solely on the balance between the inflow to the lake which is dominated by the Omo-Ghibe Basin, and the difference between evaporation and precipitation over the lake (Ngaira, 2006). Velpuri et al. (2012) show rainfall over the lake to be less important than evaporation from the lake and with a significant increase in temperature they found that evaporation from the open water in the lake could be expected to equally show a positive trend. This positive trend could unfortunately not be verified using the MODIS data as evaporation is not represented over large water bodies. Despite the expected increase in evaporation, lake levels over the last 20 years have, however, been rising. For this long time span it would seem plausible that the increasing water levels in the lake result from the positive trend in the flows from the OmoGhibe Basin, in particular in the flows during the dry season. Over the 20 years, lake levels have increased about $2 \mathrm{~m}$, which would roughly equate to a change in average annual flows of some $20 \mathrm{~m}^{3} \mathrm{~s}^{-1}$. While this is difficult to corroborate given the absence of river flow stations in the lower basin, the magnitude of the average change in the flow duration curve 
at the station at Asendabo in the upper basin, which is the most downstream station on the main stem of the river (see Fig. 4), would suggest that this is not unrealistic.

That the lake levels are sensitive to inflows is clear when shorter-term fluctuations are considered. The shorter-term fluctuations are clearly linked to the variability of the inflow to the lake from the Omo-Ghibe River - as shown by the concordance of the variability lake levels to the inflows established by Abera (2012) when lag times are considered. Arnell et al. (1996) and Bergonzini (1998) show that lakes in Africa (mostly in the Rift Valley) are very sensitive to climate variations, particularly those that are endorheic and located in semi-arid and arid regions such as Lake Turkana and Lake Chad. Additional to the seasonal variations and the longer-term trends, multi-annual trends in lake levels are influenced by extended drought or anomalous wet seasons as shown by cumulative rainfall departure analysis (Fig. 5). These fluctuations of levels are also observed in other lakes in the East African Rift Valley including lakes Victoria, Tanganyika and Malawi, with substantial drops during droughts and abrupt rises following large flood events (Mercier et al., 2002; Ngaira, 2006; Birkett et al., 1999).

\section{Conclusions}

In this paper we have applied the indicators of hydrological alteration (IHA) to study interannual trends of the natural flow regime (NFR) of an endorheic basin in southern Ethiopia. Such endorheic basins, found primarily in arid and semi-arid climates are very sensitive to changes in the climatic drivers such as rainfall, evaporation and temperature. The Omo-Ghibe Basin in southern Ethiopia is such an endorheic basin, and is the main source of water to Lake Turkana, on the Ethiopian-Kenyan border. Lake water levels fluctuate considerably at the seasonal timescale, but there are also significant longer-term trends, including a statistically significant rising trend in the water levels over the past 20 years. These fluctuations are poorly understood. Overall, the water resources infrastructure of the Omo-Ghibe Basin has until recently been poorly developed, though data, in particular in the remote lower part of the basin are scarce.

We applied a non-parametric statistical method of the IHA software to analyse the trends in the 20-30 years of available hydrological and meteorological data in the basin. We selected 17 hydrologically relevant indices from the IHA, including indices of magnitude, timing, duration, frequency and variability of flow, and assessed the significance of trends found using the non-parametric Mann-Kendall test. Trends in rainfall and temperature from terrestrial stations and evaporation from remotely sensed MODIS data were evaluated.

Of the 17 indices considered, mainly those representing low-flow magnitude, such as dry-season flow, 7-day minimum flow, BFI and dry-season FDC were found to show significantly positive trend, particularly in regions 1 and 4 .
Indices related to frequency of low flows in regions 1 and 4 also show a significantly decreasing trend, which reflects the increase in magnitude of low (dry season) flows. Little trend was found in either rainfall or wet season flows. The trend in temperature was found to be significantly increasing across the basin, but conversely trends in both potential and actual evaporation were found to be decreasing.

LULC data showed that this had changed significantly in the past 20 years, with a significant shift from forested land, woodland and woody grassland to grasslands and crop lands. This change to more seasonal and shallow-rooted land cover results in a decrease in actual evaporation and consequent increase of dry season flows. These changes are most apparent in the humid parts of the basin (regions 1 and 4), and less so in the more arid parts. In the more humid parts of the basin evaporation is in a balance between being energy limited rather than water limited, which means that an increase in the available water will more readily lead to an increase in runoff.

Variations and trends in the water levels of Lake Turkana were analysed using data from TOPEX/Posiedon, Janson-1, 2 and ENVISAT satellites as there are no ground-based data available. These data show significant variations of lake levels over the past 20-year period, including seasonal fluctuations correlated to the dry and wet season flow of the OmoGhibe Basin. Multi-annual fluctuations in lake levels were related to periods of drought or anomalously wet rainy seasons. As a significant trend in the wet season flows could not be detected based on the available data, the positive trend in lake levels over the 20-year period is considered to result from the increase in dry season flows, and thus connected to the changes in LULC in the basin.

Through applying the IHA to the Omo-Ghibe Basin, and relating trends found in the hydrological data to trends in climatological and land use data, we have identified the main drivers of change in the Omo-Ghibe Basin to likely be due to changes in LULC in the humid parts of the basin, which have led to changes in the hydrological processes, resulting in dry season flows, and subsequently to a rising trends in Lake Turkana, the end-point lake of this sensitive endorheic basin. These conclusions should, however, be considered with care as very little is as yet known of the hydrological processes in the remote lower part of the basin, where no hydrological or climatological data are available.

Acknowledgements. This research has been funded under the NPT/ETH/205 project of the Netherlands Fellowship Programmes (NFP). We would also like to acknowledge the Ministry of Water, Energy and Irrigation of Ethiopia and the National Meteorological Agency of Ethiopia for providing us with the hydro-meteorological data used.

Edited by: D. Mazvimavi 


\section{References}

Abera, G. B.: Estimating the water balance in the ungauged OmoGhibe basin, M.Sc. thesis, Hydraulic Enginering-River Basin Development, UNESCO-IHE, Delft, 109 pp., 2012.

Adnan, N. A. and Atkinson, P. M.: Exploring the impact of climate and land use changes on streamflow trends in a monsoon catchment, Int. J. Climatol., 31, 815-831, 2011.

Alemayehu, T., Furi, W., and Legesse, D.: Impact of water overexploitation on highland lakes of eastern ethiopia, Environ. Geol., 52, 147-154, 2007.

Anyamba, A.: From El Niño to La Niña: Vegetation Response Patterns over East and Southern Africa during the 1997-2000 Period, J. Climate, 15, 3096-3103, 2002.

Arnell, N., Bates, B., Lang, H., Magnusson, J. J., and Mulholland, P.: Climate Change 1995, Impacts, Adaptations and Mitigations of Climate Change: Scientific Technical Analyses, Cambridge University Press, Cambridge, 1996.

Assani, A. A., Quessy, J. F., Mesfioui, M., and Matteau, M.: An example of application: The ecological "natural flow regime" paradigm in hydroclimatology, Adv. Water Resour., 33, 537-545, 2010.

Avery, S.: Hydrological impacts of Ethiopia's Omo basin on Kenya's lake Turkana water levels \& fisheries, Prepared for the African Development Bank, Tunis, 2010.

Beadle, L. C.: The inland waters of tropical Africa: An introduction to tropical limnology, Longman London, England, 1981.

Beavis, S. G., Zhang, L., Evans, J. P., Jakeman, A. J., and Smith, D. I.: Impacts and implications of farm dams on catchment hydrology: Methods and application to chafrey catchment, MODSIM 97 IMACSt, University of Tasmania, Hobart, 1997.

Bergonzini, L.: Bilans hydriques de lacs (Kivu, Tanganyika, Rukwa et Nyassa) du rift est-africain (Water balances of lakes Kivu, Tanganyika, Rukwa and Nyasa of the East African Rift), Annales des sciences géologiques/Musée Royal de l'Afrique Centrale in Tervuren, Belgique, 103, 1-183, 1998.

Birkett, C., Murtugudde, R., and Allan, T.: Indian Ocean climate event brings floods to East Africa's lakes and the Sudd Marsh, Geophys. Res. Lett., 26, 1031-1034, 1999.

Birkett, C. M.: The contribution of TOPEX/POSEIDON to the global monitoring of climatically sensitive lakes, J. Geophys. Res., 100, 25179-25904, 1995.

Borujeni, S. C. and Sulaiman, W. N. A.: Developments of LMoment Based Models for Extreme Flood Events, Malaysian Journal of Mathematical Sciences, 3, 281-296, 2009.

Budyko, M. I.: Climate and Life, in: International geophysics series, edited by: Miller, D. H., English Ed. Academic Press, New York, 1974.

Carlisle, D. M., Falcone, J., Wolock, D. M., Meador, M. R., and Norris, R. H.: Predicting the natural flow regime: Models for assessing hydrological alteration in streams, River Res. Appl., 26, 118-136, 2010.

Cassardo, C. and Jones, J. A. A.: Managing water in a changing world, Water, 3, 618-628, doi:10.3390/w3020618, 2011.

Cheung, W. H., Senay, G. B., and Singh, A.: Trends and spatial distribution of annual and seasonal rainfall in Ethiopia, Int. J. Climatol., 28, 1723-1734, doi:10.1002/joc.1623, 2008.

Conway, D.: Extreme Rainfall Events and Lake Level Changes in East Africa: Recent Events and Historical Precedents, in: The East African Great Lakes: Limnology, Palaeolimnology and Bio- diversity, edited by: Odada, E. O. and Olago, D. O., Kluwer Academic Publisher, the Netherlands, 62-92, 2002.

Crétaux, J. F., Letolle, R., and Kouraev, A.: Aral Sea Level Variability, The Handbook of Environmental Chemistry, edited by: Kostianov, A. G. and Kosarev, A. N., The Aral sea Environment, 181-193, 2010.

Crétaux, J.-F., Jelinski, W., Calmant, S., Kouraev, A., Vuglinski, V., Bergé-Nguyen, M., Gennero, M.-C., Nino, F., Abarca Del Rio, R., and Cazenave, A.: SOLS: A lake database to monitor in the Near Real Time water level and storage variations from remote sensing data, Adv. Space Res., 47, 1497-1507, 2011.

CSA: Summary and Statistical Report of the 2007 Population and Housing Census, FDRE Central Statistical Agency, Addis Ababa, 2007.

Dikbas, F., Firat, M., Koc, A. C., and Gungor, M.: Defining Homogeneous Regions for Streamflow Processes in Turkey Using a K-Means Clustering Method, Arab. J. Sci. Eng., 38, 1313-1319, doi:10.1007/s13369-013-0542-0, 2013.

Ebei, P. A., Oba, G., and Akuja, T.: Long-term impacts of droughts on pastoral production and trends in poverty in North-western Kenya: An evaluation of 14-year drought early warning data series, in: Droughts: Causes, effects and predictions, edited by: Sánchez, J. M., NOVA Science Publishers, Inc., New York, 103138, 2008.

EEPCO: Gibe III Hydroelectric Project: Environmental and Social Management Plan, The Federal Democratic Republic of Ethiopia Ethiopian Electric Power Corporation, Addis Ababa, 2009.

EEPCO: Gilgel Gibe I Hydroelectric Project: Final Report on the Project Implementation, The Federal Democratic Republic of Ethiopia Ethiopian Electric Power Corporation, Addis Ababa, 2004a.

EEPCO: Gilgel Gibe II Hydro-Electric project, The Federal Democratic Republic of Ethiopia Ethiopian Electric Power Corporation, Addis Ababa, 2004b.

Emiru, N., Gebrekidan, H., and Tibebe, D.: Analysis of land use/land cover changes in western Ethiopian mixed croplivestock systems: the case of Senbat watershed, Journal of Biodiversity and and Environmental Sciences (JBES), 2, 8-17, 2012.

ESA: GlobeCover, available at: http://due.esrin.esa.int/globcover/, last access: 15 August 2012, 2010.

FAO: Land Cover Classification System (LCCS), FAO, Rome, Italy, 2000.

Fissekis, A. D.: The Effects of Flow Regime and Land Use Practices on Ecological Health in the Grand Ronde Sub-basin, The Center for Watershed Sciences, California, 2007.

FDRE National Meteorological Agency: Climate change National Adaptation Programme of Action (NAPA) of Ethiopia, National Meteorological Agency, Addis Ababa, 2007.

Ferguson, A. J. D. and Harbott, B. J.: Geographical, physical and chemical aspects of Lake Turkana Overseas Development Administration, London, UK, 1-107, 1982.

Gottschalk, L.: Hydrological regionalization of Sweden, Hydrol. Sci. J., 30, 65-83, 1985.

Haines, A. T., Finlayson, B. I., and McMahon, T. A.: A global classification of river regimes, Appl. Geogr., 8, 255-272, 1988.

Hall, M. J. and Minns, A. W.: The classification of hydrologically homogeneous regions, Hydrol. Sci., 44, 693-704, 2009.

Hansen, M., DeFries, R., Townshend, J. R. G., and Sohlberg, R.: UMD Global Land Cover Classification, 1 Kilometer, 1.0, 
Department of Geography, University of Maryland, College Park, Maryland, 1981-1994, 1998.

Harris, N. M., Gurnell, M. A., Hannah, D. M., and Petts, G. E.: Classification of river regimes: a context for hydroecology, Hydrol. Process., 14, 2831-2848, 2000.

Hopson, A. J.: Lake Turkana, A Report on the Findings of the Lake Turkana Project, 1972-75, Overseas Development Administration, London, 1982.

Hosking, J. R. M.: L-moment: Analysis and estimation of distributions using linear combination of order statistics, J. Roy. Stat. Soc. B Met., 52, 105-124, 1990.

Hosking, J. R. M. and Wallis, J. R.: Regional skew in search of a parent, Water Resour. Res., 29, 1745-1752, 1993.

Hosking, J. R. M. and Wallis, J. R.: Regional frequency analysis: An approach based on L-moments, Cambridge univeristy press, Cambridge, UK, 1997.

Huh, S., Dickey, D. A., Meador, M. R., and Ruhl, K. E.: Temporal analysis of the frequency and duration of low and high streamflow: years of record needed to characterize streamflow variability, J. Hydrol., 310, 78-94, 2005.

Infoplease: Country maps - Africa, ${ }^{\circledR}$ 2000-2014 Pearson Education, publishing as Infoplease, available at: http://www. infoplease.com/atlas/africa.html (last access: 11 May 2012), 2012.

Kadukin, A. I. and Klige, R. K.: The water balance of the Caspian Sea and Aral Sea, in: Hydrology of Natural and manmade Lakes, Proceedings of the Vienna Symposium, Vienna, Austria, IAHS Publ. No. 206, 55-60, 1991.

Kendall, M. G.: Rank Correlation Methods, Book Series, Charles Griffin, Oxford University Press, USA, London, 1975.

Krasovkaia, I.: Entropy-based grouping of river flow regimes, J. Hydrol., 202, 173-191, 1997.

Lorup, J. K., Refsgaard, J. C., and Mazvimavi, D.: Assessing the effect of land use change on catchment runoff by combined use of statistical tests and hydrological modeling: case study from Zimbabwe, J. Hydrology, 205, 147-163, 1998.

Lytle, D. A. and Poff, N. L.: Adaptation to natural flow regimes, Trends Ecol. Evol., 19, 94-100, 2004.

Magole, L., Borgtoft Pedersen, H., and Klinte, L.: An Introduction to the Okavango Delta Management Plan, HOORC \& DEA, Maun, Botswana, 2009.

Maidment, D. R. and Hersh, E. S.: Assessment of Hydrologic Alteration Software: FINAL REPORT Center for Research in Water Resources, The University of Texas at Austin, Austin, USA, 2006.

Mann, H. B.: Non-parametric test aganist trend, Econometrica, 13, 245-259, 1945.

Mao, D. and Cherkauer, K. A.: Impacts of land-use change on hydrologic responses in the Great Lakes region, J. Hydrol., 374, 71-82, 2009.

Masih, I., Maskey, S., Uhlenbrook, S., and Smakhtin, V.: Impact of upstream changes in rainfed agriculture on downstream flow in a semi-arid basin, Agr. Water Manage., 100, 36-45, doi:10.1016/j.agwat.2011.08.013, 2011.

Mercier, F., Cazenave, A., and Maheu, C.: Interannual lake level fluctuations (1993-1999) in Africa from Topex/Poseidon: connections with ocean-atmosphere interactions over the Indian Ocean, Global Planet. Change, 32, 141-163, doi:10.1016/S09218181(01)00139-4, 2002.
Mitchell, T. D. and Jones, P. D.: An improved method of constructing a database of monthly climate observations and associated high-resolution grids, Int. J. Climatol., 25, 693-712, 2005.

Monteith, J. L.: Evaporation and Environment, in: 19th Symposia of the Society for Experimental Biology, University Press, Cambridge, 19, 205-234, 1965.

$\mathrm{Mu}$, Q., Zhao, M., and Running, S. W.: Improvements to a MODIS global terrestrial evapotranspiration algorithm, Remote Sens. Environ., 115, 1781-1800, 2011.

Nejadhashemi, A. P., Wardynski, B. J., and Munoz, J. D.: Evaluating the impacts of land use changes on hydrologic responses in the agricultural regions of Michigan and Wisconsin, Hydrol. Earth Syst. Sci. Discuss., 8, 3421-3468, doi:10.5194/hessd-83421-2011, 2011.

Newson, M. D.: Land, Water and Development: Sustainable Management of River Basin Systems, Routledge, London, 1997.

Ngaira, J. K.: Implications of climate change on the management of Rift Valley lakes in Kenya. The case of lake Baringo, in: Proceedings of the 11th World Lakes Conference, edited by: Odada, E. and Olago, D. O., 2, 133-138, 2006.

Ogallo, L.: Climate variability and change in Africa: a review of potential impacts on terrestrial water resources, in: Groundwater and Climate in Africa, Proceedings of the Kampala Conference, June 2008, Uganda, IAHS Publ. 334, 47-51, 2009.

Oki, T., Blyth, E. M., and Berbery, E. H.: Land Cover and Land use Change and their impacts on Hydroclimate, Ecosystems and Society, WCRP Open Science Conference, Denver, Colorado, 2011.

Olden, J. D. and Poff, N. L.: Redundancy and the Choice of Hydrologic Indices for Characterizing Streamflow Regimes, River Res. Appl., 19, 101-121, 2003.

Pikounis, M., Varanou, E., Baltas, E., Dassaklis, A., and Mimikou, M.: Application of the SWAT model in the Pinios river basin under different land-use scenarios, Global NEST J., 5, 71-79, 2003.

Poff, N. L. and Zimmerman, J. K.: Ecological responses to altered flow regimes: a literature review to inform the science and management of environmental flows, Freshwater Biol., 55, 194-205, 2010.

Poff, N. L., Allan, J. D., Bain, M. B., Karr, J. R., Prestegaard, K. L., Richter, B. D., Sparks, R. E., and Stomberg, J. C.: The natural flow regime. A paradigm for river conservation and restoration, BioScience, 47, 769-784, 1997.

Poff, N. L., Bledsoe, B. P., and Cuhaciyan, C. O.: Hydrologic variation with land use across the contiguous United States: Geomorphic and ecological consequences for stream ecosystems, Geomorphology, 79, 264-285, 2006.

Richter, B. D., Baumgartner, J. V., Powell, J., and Braun, D. P.: A method for assessing hydrologic alteration within ecosystems, Conserv. Biol., 10, 1163-1174, 1996.

Richter, B. D., Baumgartner, J. V., Wigington, R., and Braun, D. P.: How much water does a river need?, Freshwater Biol., 37, 231249, 1997.

Rientjes, T. H. M., Haile, A. T., Kebede, E., Mannaerts, C. M. M., Habib, E., and Steenhuis, T. S.: Changes in land cover, rainfall and stream flow in Upper Gilgel Abbay catchment, Blue Nile basin - Ethiopia, Hydrol. Earth Syst. Sci., 15, 1979-1989, doi:10.5194/hess-15-1979-2011, 2011.

Risbey, J. S. and Entekhabi, D.: Observed Sacramento Basin streamflow response to precipitation and temperature changes 
and its relevance to climate impact studies, J. Hydrol., 184, 209223, 1996

Rost, S., Gerten, D., Bondeau, A., Lucht, W., Rohwer, J., and Schaphoff, S.: Agricultural green and blue water consumption and its influence on the global water system, Water Resour. Res., 44, 1-17, doi:10.1029/2007WR006331, 2008.

Sankarasubramanian, A., Vogel, R. M., and Limbrunner, J. F.: The Climate elasticity of streamflow in the United States, Water Resour. Res., 37, 1771-1781, 2001.

Sayed, M. A. A.: Eastern Nile Planning Model, Integration with IDEN Projects To Deal with Climate Change Uncertainty and Flooding Risk, Nile Basin Water Eng.'g Sci. Mag., 1, 86-93, 2008.

Schilling, K. E., Jha, M. K., Zhang, Y. K., Gassman, P. W., and Wolter, C. F.: Impact of land use and land cover change on the water balance of a large agricultural watershed: Historical effects and future directions, Water Resour. Res., 44, W00A09, doi:10.1029/2007WR006644, 2008.

Sen, P. K.: Estimates of the regression coefficient based on Kendall's tau, J. Am. Stat. Assoc., 63 1379-1389, 1968.

Sima, B. A.: Flow Regime and Land Cover Changes In the Didessa Sub-Basin of the Blue Nile River, South - Western Ethiopia, M.Sc. thesis, Department of Aquatic Science and Assessment, Swedish University of Agricultural Sciences, Uppsala, Sweden, 63 pp., 2011.

Siriwardena, L., Finlayson, B. L., and McMahon, T. A.: The impact of land use change on catchment hydrology in large catchments: The Comet River, Central Queensland, Australia, J. Hydrol., 326, 199-214, 2006.

Stanford, J. A., Ward, J., Liss, W. J., Frissell, C. A., Williams, R. N., Lichatowich, J. A., and Coutant, C. C.: A general protocol for restoration of regulated rivers, Regul. River., 12, 391-413, 1996.

Survey of Kenya: National Atlas of Kenya, Nairobi, 15-21, 1977.

The Nature Conservancy: Indicators of Hydrologic Alteration Version 7.1 Uuser's Manual, The Nature Conservancy, 1-76, 2009.

Tomer, M. D. and Schilling, K. E.: A simple approach to distinguish land-use and climate-change effects on watershed hydrology, J. Hydrol., 376, 24-33, 2009.

Trambauer, P., Dutra, E., Maskey, S., Werner, M., Pappenberger, F., van Beek, L. P. H., and Uhlenbrook, S.: Comparison of different evaporation estimates over the African continent, Hydrol. Earth Syst. Sci., 18, 193-212, doi:10.5194/hess-18-193-2014, 2014
UNEP: World atlas of desertification 2ED, United Nations Environment Programme, London, 1997.

Van Kirk, R. W. and Naman, S. W.: Relative Effects of Climate and Water Use on Base-Flow Trends in the Lower Klamath Basin1, J. Am. Water Resour. As. (JAWRA), 44, 1035-1052, 2008.

Van Steeter, M. M. and Pitlick, J.: Geomorphology and endangered fish habitats of the upper Colorado River: 1. Historic changes in streamflow, sediment load, and channel morphology, Water Resour. Res., 34, 287-302, 1998.

Velpuri, N. M., Senay, G. B., and Asante, K. O.: A multi-source satellite data approach for modelling Lake Turkana water level: calibration and validation using satellite altimetry data, Hydrol. Earth Syst. Sci., 16, 1-18, doi:10.5194/hess-16-1-2012, 2012.

Viglione, A., Laio, F., and Claps, P.: A comparison of homogeneity tests for regional frequency analysis, Water Resour. Res., 43 , W03428, doi:10.1029/2006WR005095, 2007.

Wolski, P., Murray-Hudson, M., Savenije, H., and Gumbricht, T. Modelling of the hydrology of the Okavango Delta Harry Oppenheimer Okavango Research Centre University of Botswana, MaunEU funded project ICA-4-CT-2001-10040, 2005.

Wooldridge, S., Kalma, J., and Kuczera, G.: Parameterization of a simple semi-distributed model for assessing the impact of landuse on hydrology response, J. Hydrology, 254, 16-32, 2001.

World Bank: GEF project on the Lake Chad Experience and Lessons Learned brief, World Bank, Washington D.C., 2006.

Yang, D., Shao, W., Yeh, P. J. F., Yang, H., Kanae, S., and Oki, T. Impact of vegetation coverage on regional water balance in the nonhumid regions of China, Water Resour. Res., 45, W00A14, doi:10.1029/2008WR006948, 2009.

Yang, Z., Zhou, Y., Wenninger, J., and Uhlenbrook, S.: The causes of flow regime shifts in the semi-arid Hailiutu River, Northwest China, Hydrol. Earth Syst. Sci., 16, 87-103, doi:10.5194/hess16-87-2012, 2012

Yuretich, R. F. and Cerling, T. E.: Hydrogeochemistry of Lake Turkana, Kenya: mass balance and mineral reactions in an alkaline lake, Geochim. Cosmochim. Ac., 47, 1099-1109, 1983.

Zhang, L., Dawes, W. R., and Walker, G. R.: Response of mean annual evapotranspiration to vegetation changes at catchment scale, Water Resour. Res., 37, 701-708, 2001. 